Brit. J. industr. Med., 1962, 19, 239.

\title{
HARD METAL DISEASE
}

\author{
BY \\ A. O. BECH, M. D. KIPLING, and J. C. HEATHER \\ From the Coventry Group of Hospitals and H.M. Medical Inspector of Factories, Birmingham
}

(RECEIVED FOR PUBLICATION DECEMBER 23, 1961)

\begin{abstract}
In Great Britain there have been no published reports of respiratory disease occurring amongst workers in the hard metal (tungsten carbide) industry. In this paper the clinical and radiological findings in six cases and the pathological findings in one are described. In two cases physiological studies indicated mild alveolar diffusion defects. Histological examination in a fatal case revealed diffuse pulmonary interstitial fibrosis with marked peribronchial and perivascular fibrosis and bronchial epithelial hyperplasia and metaplasia. Radiological surveys revealed the sporadic occurrence and low incidence of the disease. The alterations in respiratory mechanics which occurred in two workers following a day's exposure to dust are described. Airborne dust concentrations are given.

The industrial process is outlined and the literature is reviewed. The toxicity of the metals is discussed, and our findings are compared with those reported from Europe and the United States.

We are of the opinion that the changes which we would describe as hard metal disease are caused by the inhalation of dust at work and that the component responsible may be cobalt.
\end{abstract}

Hard metal is manufactured by a process of powder metallurgy from tungsten and carbon with cobalt as a binder. The industry, starting in Germany after the first world war, has greatly increased in size. The extremely hard product ( 90 to $95 \%$ the hardness of diamond) is used for the cutting edges of tools, rock drills, broaches, and dies. It is also used for radiotherapy screens and armaments.

The process of manufacture involves the production of tungsten metal powder and cobalt powder from their respective oxides or salts. The tungsten metal powder is mixed with carbon and heated in an atmosphere of hydrogen to form tungsten carbide. Titanium carbide is added in some grades and is similarly formed. Small amounts of tantalum carbide and vanadium carbide may be incorporated in particular grades.

The percentage by weight of tungsten carbide varies from 80 to 90 , of titanium carbide 8 to 18 and of cobalt 5 to 25 . More than three-quarters of production is of grades containing between $6 \%$ and $9 \%$ of cobalt.

Carbides and cobalt are mixed wet in a ball-mill and dried. The dried powder is pressed to the required shape combined with wax using a solvent such as trichlorethylene, which is then driven off by heat in an oven in an atmosphere of hydrogen (presintering). After shaping, the product is heated again in an atmosphere of hydrogen (sintering). It is then ground, wet or dry, with diamond and carborundum wheels to its final shape.

Dust may be produced during mixing, filtering, shaping, and grinding, but since the material is valuable and contamination of the product by other dust undesirable, as much dust as possible is recovered by local exhaust.

The sequence of the various manufacturing processes is outlined in the chart (Fig. 1).

\section{Historical Review}

Jobs and Ballhausen (1940) examined 27 workers in a factory which had been in production for two years in Germany and found reticular shadowing with areas of fine nodulation suggestive of early pneumoconiosis in the radiographs of eight men who had been exposed to hard metal dust. Wiele (1951) in Germany reported that the radiographs of two men showed a pneumoconiosis. These men had been employed in powder mixing for 10 and 30 years respectively. The first suffered from severe dyspnoea and the other died of cardiac failure due to emphysema and chronic bronchitis.

Moschinski, Jurisch, and Reinl (1959) examined 696 hard metal workers between the years 1948 and 1949 and found a high incidence of bronchitis with 


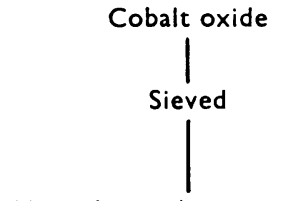

Heated in reduction oven in hydrogen at $600-1000^{\circ} \mathrm{C}$.

Cobalt metal powder

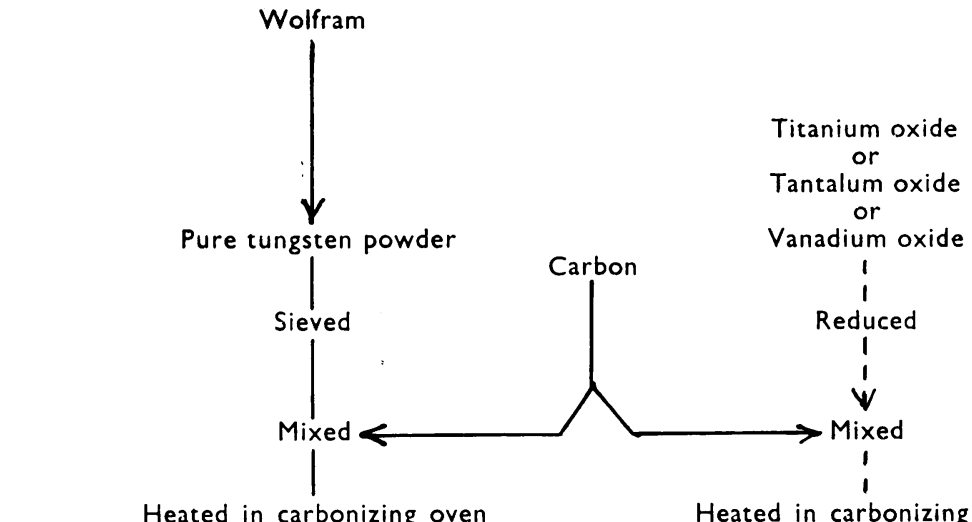

Heated in carbonizing oven in hydrogen at $1400-1500^{\circ} \mathrm{C}$.

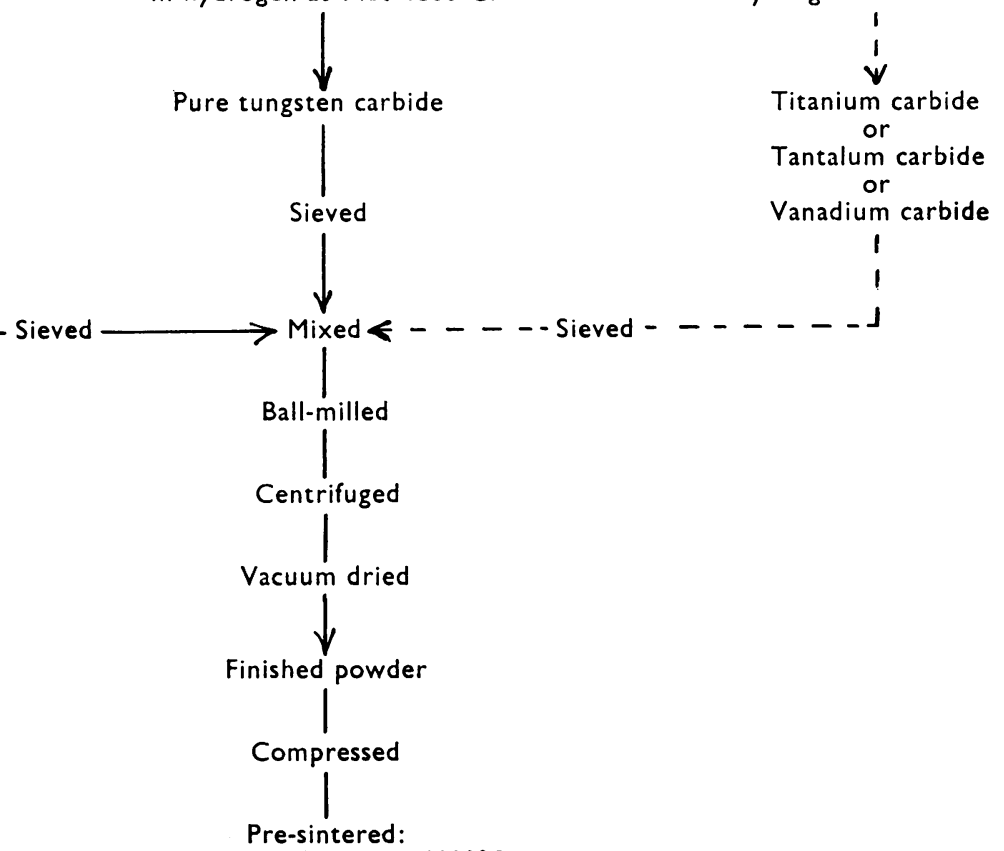

Heated in hydrogen at $1000^{\circ} \mathrm{C}$.

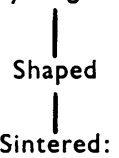

Heated in hydrogen at $1500^{\circ} \mathrm{C}$.

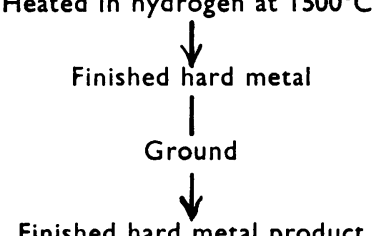

Finished hard metal product 
bronchospasm. They quote a report of Magos, Timár, and Szandányi (1956) on Hungarian hard metal workers. Of 40 workers 23 complained of respiratory difficulties, and in the radiographs of five of these there was a stippled network appearance and in the rest a demonstrable increase in lung markings.

In 1955 and 1956 Moschinski et al. (1959) carried out an investigation amonst 331 hard metal workers. They found a high incidence of respiratory disorders and radiographic changes in 59 men; of these 20 showed early fibrosis, 38 a slightly more advanced degree, and one marked changes. The changes most frequently seen were diffuse finely striated increased lung markings in the mid and lower zones and in more advanced cases soft patchy nodular opacities extending over the lung fields, also thickening of the hilar shadows and fairly large irregular shadows in the mid-zones. The particulars of three cases were reported in detail. These authors concluded that respiratory disorders developed after varying periods of exposure, the main symptoms being difficulty in breathing, cough, and expectoration, and that the clinical picture was characterized by the development of bronchitis with bronchospasm and in severe cases by emphysema and respiratory insufficiency. They had observed fibrosis develop in a few instances following a preliminary phase with respiratory symptoms. The possibility of susceptibility was also discussed.

Husten (1959) described the post-mortem findings in a man whose case had been originally described by Wiele. He found diffuse pulmonary fibrosis, emphysematous changes and interstitial fibrosis particularly in the pulmonary lobules, also an associated pulmonary tuberculosis. Titanium and tungsten were detected chemically in the pulmonary and lymphatic tissues but not cobalt.

In Sweden, Karth (1948) described three cases. These men suffered from cough and marked dyspnoea, and the appearances of their radiographs were suggestive of chronic interstitial pneumonia. Two of the cases at autopsy showed non-specific interstitial pneumonia.

Lundgren and Öhman (1954) quote Forssman as stating he had seen 11 cases of pulmonary disease amongst hard metal workers while in the U.S.A. in 1947 and Frederick that 15 to 16 cases had occurred in two Detroit factories, one of which had been visited by Forssman. In two fatal cases there were fibrosis, thickening of alveolar walls, and giant cells in the alveoli and small bronchi. Analysis of the lungs revealed the presence of titanium and tungsten but virtually no cobalt. This was attributed to the greater solubility of cobalt. Lundgren and Öhman (1954) reported personal experience of five cases of pulmonary fibrosis among Swedish hard metal workers and the autopsy findings in two fatal cases. They also carried out a survey amongst approximately 200 hard metal workers in five factories and gave a detailed account of their findings.

Ahlmark, Bruce, and Nyström (1961) in a summary of four recorded cases of pneumoconiosis attributed to hard metal state that after relatively short periods of employment, at most eight years, pulmonary lesions were found characterized by proliferation of interstitial tissue and a tendency to pulmonary contraction, and that the pneumoconiosis showed a marked tendency to progress.

In the U.S.A., Fairhall, Castberg, Carrozzo, and Brinton (1947) examined 1,802 tungsten carbide workers. They found changes in the conjunctivae, the upper respiratory tract, and the mucous membranes. Pruritus and sensitivity to cobalt as shown by patch tests were found in some workers. In the radiographs of 36 there were granular or conglomerate markings, but $64 \%$ of these men had been previously employed in mining or metal fabricating industries.

Miller, Davis, Goldman, and Wyatt (1953) described three cases. These men were engaged in grinding finished hard metal tools. They complained of persistent cough with sputum and dyspnoea on exertion, and their radiographs showed prominent hilar shadows and increased lung markings. They quote Olsen in a personal report as having studied cases of hard metal workers with radiographic changes during the war in Sweden.

Schwartz, Peck, Blair, and Markuson (1945) investigated dermatitis in a tungsten carbide plant and came to the conclusion that sensitivity to cobalt was the cause of the dermatitis. Moschinski et al. (1959) confirmed that cobalt was a cutaneous sensitizer.

In Russia, Kaplun (1957) examined the workers in two hard metal factories and found cases of lung disease. In Czechoslovakia, Kaplun and Mezencewa (1960) analysed the records of periodic medical examinations of 283 hard metal workers and found that disorders of the upper respiratory tract, bronchitis, and an early type of pneumoconiosis occurred.

In this country A.I.G. McLaughlin (1961, personal communication) investigated a hard metal worker whose chest radiographs revealed marked changes. [In 1951 the workers in a hard metal factory were surveyed by Davidson and Cottrell (P. T. Davidson and J. E. Cottrell, personal communication); the latter is quoted by Browning (1960). Davidson (1962, personal communication) carried out a further survey at the same factory.] 
Toxicity of Cobalt, Tungsten and Titanium

The literature relating to the toxicity of tungsten, cobalt, titanium and tantalum has been reviewed by Browning (1961), and of cobalt by Caujolle and Meynier (1959).

Frederick and Bradley (1946) found tungsten, tantalum and titanium carbides, and titanium oxide essentially inert in white rats when injected intraperitoneally. Cobalt metal produced marked vasodilatation, swelling of the liver, moderate blood changes characterized by an increased number of immature red cells, and initial inflammation with residual fibrosis in all tissue surfaces in contact with the material. Cobalt was not stored in the animal organism. Miller et al. (1953) produced an intense foreign body reaction and early collagenic sclerosis by injection of dust derived from grinding into the peritoneal cavities of rats. Intratracheal inoculation of pure tungsten carbide produced no changes other than those of an inert dust after 18 weeks. Delahant (1955) compared the effect of intratracheal injection into guinea-pigs of tantalum oxide, tungsten metal, cobalt oxide, tungsten carbide and carbon (ratio 94 to 6), tungsten carbide and cobalt (ratios 3 to 1 and 91 to 9), and cobalt metal. He found cobalt metal was intensely irritant to pulmonary tissue and that the property remained when cobalt was combined with tungsten carbide. A second injection of cobalt after one week produced a fatal reaction in five out of six animals.

Schepers (1955), using a similar technique, found tantalum oxide was essentially benign but there were minor bronchial epithelial hyperplasia and hypertrophic focal emphysema. Cobalt oxide produced a transient inflammatory reaction. He considered that tungsten was relatively benign but found that cobalt produced a chemical pneumonitis. In the subacute lesions there was a predominance of eosinophil cells and incipient adenoma formation. There was evidence of the development of tolerance to cobalt. With intratracheal injection of tungsten carbide and carbon (ratio 94 to 6) there was an acute response with hyperaemia and bronchial catarrh and minor residual changes. Tungsten carbide and cobalt (ratio 10 to 1 ) caused a transient inflammatory response with residual fibrosis. The inhalation of tungsten carbide and cobalt (ratio 3 to 1) produced acute inflammation followed by focal pneumonitis with residual bronchial epithelial hyperplasia and metaplasia. He stressed the unusual epithelial reaction following intratracheal injection of tungsten carbide and cobalt mixtures.

Kaplun (1957) exposed dogs for four months to an atmosphere containing a concentration of $200 \mathrm{mg}$./ $\mathrm{m}^{3}$ of metallic cobalt, and found a lowering of blood pressure and pathological changes in the lungs.
Kaplun and Mezencewa (1960) administered tungsten carbide, metallic tungsten, tungsten oxide, titanium carbide, cobalt oxide, metallic cobalt, and a mixture of tungsten, titanium, and cobalt to white rats in a dust chamber or by intratracheal injection. Metallic tungsten, tungsten oxide, tungsten carbide, and titanium carbide produced only very minor changes. Cobalt produced perivascular and peribronchial inflammatory changes with fibrosis and in the bronchi small rounded epithelial glandular formations. They found that cobalt oxide produced similar changes. Mixtures of tungsten, titanium, and cobalt were more toxic than metallic cobalt alone. The changes seen were perivascular and peribronchial inflammatory changes and fibrosis. The epithelium of the smaller bronchi was hypertrophied forming tumours and adenoma-like structures. These changes were similar to those caused by cobalt but much more advanced. They considered that the increased effect of cobalt in mixtures with tungsten was due to the fact that tungsten dust increased the solubility of cobalt.

Harding (1950) in experiments on rats found that intratracheal injection of cobalt metal powder had an acute irritant reaction and produced marked alterations in the pulmonary capillaries with an outpouring of fluid and haemorrhages. $\mathrm{He}$ considered that this action was related to the solubility of cobalt in protein-containing fluids, which is $\mathbf{5 0 0}$ times greater than in saline. Tungsten and pure tungsten carbide injections did not produce similar toxic changes.

Heath (1960) produced malignant tumours in 17 out of 30 rats by a single injection of pure metallic cobalt.

Changes in the serum protein fractions of the blood after cobalt administration were described by Volta and Marinoni (1951), by Uzman and Rosen (1954) and by Stokinger and Wagner (1958). Erythrocytaemia has been demonstrated by many observers in humans and animals following administration of cobalt (Browning, 1961) and a rise in haemoglobin was found in cobalt workers ( $\mathrm{J}$. Gwynne Morgan, 1961, personal communication). S. G. Rainsford (1960, personal communication) found haemoglobin levels above $16.0 \mathrm{~g}$. per $100 \mathrm{ml}$. in three out of five hard metal workers examined by him.

\section{Present Series}

Preliminary Observations.-During the past 14 years four men had been referred to hospital in the Coventry area, in whom either the occupational or clinical histories suggested the possibility of hard metal disease. The cases of these men together with two others are reported below. Our clinical impres- 
TABLE 1

RESULTS OF PHYSIOLOGICAL TESTS

\begin{tabular}{|c|c|c|c|c|c|c|c|c|}
\hline \multirow{2}{*}{ Subject } & \multirow{2}{*}{ Type of Work } & \multirow{2}{*}{$\begin{array}{c}\text { Duration } \\
\text { (years) }\end{array}$} & \multicolumn{3}{|c|}{ F.E.V.1.0 } & \multicolumn{3}{|c|}{$\begin{array}{c}\text { Inspiratory Airways Resistance } \\
\text { (A.W.R. Units) }\end{array}$} \\
\hline & & & A.M. & P.M. & $\%$ Change & A.M. & P.M. & $\%$ Change \\
\hline $\begin{array}{l}\mathbf{A} \\
\mathbf{B} \\
\mathbf{C} \\
\mathbf{D} \\
\mathbf{E} \\
\mathbf{F} \\
\mathbf{G}\end{array}$ & & Mean & $3 \cdot 14$ & $3 \cdot 18$ & +1.3 & 0.77 & 0.69 & $-8 \cdot 1$ \\
\hline \multirow[t]{2}{*}{$\begin{array}{l}\mathbf{H} \\
\mathbf{I} \\
\mathbf{J} \\
\mathbf{K} \\
\mathbf{L} \\
\mathbf{M} \\
\mathbf{N} \\
\mathbf{O} \\
\mathbf{P} \\
\mathbf{Q} \\
\mathbf{R} \\
\mathbf{S}\end{array}$} & $\begin{array}{l}\text { Shaping Department } \\
\text { Turner } \\
\text { Grinder } \\
\text { Cutter grinder } \\
\text { Cutter grinder } \\
\text { Hot press operator } \\
\text { Press operator } \\
\text { Turner } \\
\text { Cutter grinder } \\
\text { Cutter grinder } \\
\text { Grinder } \\
\text { Inspection } \\
\text { Progress }\end{array}$ & $\begin{array}{c}10 \\
16 ! \\
3 ! \\
6 \\
3 \\
3 \\
10 \\
11 \\
7 \\
11 \\
6 \\
5 \\
10\end{array}$ & $\begin{array}{l}2 \cdot 27 \\
4 \cdot 15 \\
2 \cdot 88 \\
2 \cdot 27 \\
3 \cdot 73 \\
2 \cdot 78 \\
3.67 \\
4 \cdot 15 \\
1.77 \\
3.48 \\
2.70 \\
2.65\end{array}$ & $\begin{array}{l}1.87 \\
4 \cdot 10 \\
2.95 \\
2.43 \\
3.23 \\
3.63 \\
3.73 \\
3.94 \\
2.24 \\
3.54 \\
2.79 \\
2.67\end{array}$ & $\begin{array}{r}-17.6 \\
-\quad 1.2 \\
-\quad 2.4 \\
+\quad 7.0 \\
-13.4 \\
-5.4 \\
+\quad 1.6 \\
-5.1 \\
+26.6 \\
+\quad 1.7 \\
+\quad 3.2 \\
+\quad 0.8\end{array}$ & $\begin{array}{l}0.66 \\
0.45 \\
0.78 \\
1.33 \\
0.66 \\
0.62 \\
0.39 \\
1.43 \\
1.03 \\
0.71 \\
0.63 \\
0.69\end{array}$ & $\begin{array}{l}0.82 \\
0.58 \\
0.80 \\
1.69 \\
0.87 \\
0.57 \\
0.55 \\
0.88 \\
0.88 \\
0.51 \\
0.61 \\
0.55\end{array}$ & $\begin{array}{r}+24.3 \\
+28.9 \\
+\quad 2.6 \\
+27.1 \\
+31.8 \\
+8.1 \\
+41.0 \\
-38.5 \\
-14.6 \\
-28.2 \\
-3.2 \\
-20.3\end{array}$ \\
\hline & & Mean & 3.04 & 3.01 & -0.4 & $0 \cdot 78$ & 0.78 & +3.6 \\
\hline
\end{tabular}

sion was that these men had contracted a pulmonary disease from exposure to dust at work. One man, who had been under clinical and radiological supervision for several years, developed this disorder after a short period of exposure. A physiological evaluation was obtained in two, which indicated pulmonary fibrosis and minor alveolar diffusion defects and supported our clinical impressions of the disease.

A study of these cases led us to undertake a radiological survey of 255 hard metal workers at six factories. As there had been complaints that a number of workers noticed tightness of the chest during the working day we carried out some simple physiological tests on 19 volunteers at one factory to see whether the ventilatory capacity and airways resistance could be shown to change during a normal day's exposure. At the same time dust concentrations were estimated at the same factory.

\section{Survey of 255 Hard Metal Workers.}

Radiography.-Radiological surveys of 232 hard metal workers ( 22 powder workers, 113 shapers, and 97 grinders) were carried out by the Mass Radiography Units using $70 \mathrm{~mm}$. films and of 23 grinders using full-sized films. One case of hard metal disease (Case 5) was discovered, and in the radiographs of several other workers there were slight changes which we considered to be due to early fibrosis. Cases 1, 2, 4, and 6 were discovered during routine visits of the Mass Radiography Unit in the past 15 years.
Physiological Tests.-Seven powder workers and 12 shapers had estimations of the forced expiratory volume $($ F.E.V.1.0 $)$ and of airways resistance (A.W.R.) (McKerrow, Roach, Gilson, and Schilling, 1962) carried out at the start and at the end of a working day. The results are in Table 1.

Among those tested there were two subjects " $\mathrm{H}$ " and " $L$ " in whom a considerable fall in ventilatory capacity was accompanied by an appreciable rise in airways resistance. There were two other subjects "I" and "N" whose A.W.R. rose considerably during the day, but this was not accompanied by any changes in the F.E.V. It was thought that these changes could possibly be due to a technical cause in the A.W.R. measurement. Subjects " $J$ " and " $S$ " showed no physiological changes, although in the past, before they wore masks, they had complained of tightness in the chest during work.

The results showed that there was little change in respiratory mechanics with the exception of subjects " $K$ " and " $L$ " both of whom complained of wheezing and tightness.

Environmental Studies.-Airborne dust samples were collected at breathing level in the different departments of the factory by a thermal precipitator. The dust counts comprised all particles in the size range 0.5 to $5.0 \mu$ projected diameter, thus including any general atmospheric pollution component. The gravimetric samples obtained with a conicycle (Wolff and Roach, 1961) were taken in the sieving room (subject " $B$ ") and in the hot press department 
TABLE 2

AIRBORNE DUST CONCENTRATIONS

\begin{tabular}{|c|c|c|c|}
\hline \multirow[b]{2}{*}{ Department } & \multirow[b]{2}{*}{ Operation } & \multicolumn{2}{|c|}{ Concentration } \\
\hline & & $\begin{array}{c}\text { p.p. ml. } \\
(0.5 \text { to } 5 \mu)\end{array}$ & $\underset{(<5 \mu)}{\mathrm{mg}} / \mathrm{m}^{3}$ \\
\hline Powder & $\begin{array}{l}\text { Weighing } \\
\text { Sieving } \\
\text { Granulating }\end{array}$ & $\begin{array}{l}505 \\
483 \\
405\end{array}$ & $0 \cdot 30$ \\
\hline Forming & $\begin{array}{l}\text { Turning } \\
\text { Cutter grinding } \\
\text { Slitting } \\
\text { Hot pressing } \\
\text { Cold pressing }\end{array}$ & $\begin{array}{c}405 \\
230-475 \\
1,230 \\
410 \\
195\end{array}$ & $\begin{array}{l}0.34 \\
0.30\end{array}$ \\
\hline Outside factory & & $100-150$ & \\
\hline
\end{tabular}

TABLE 2a

ANALYSIS OF INCOMBUSTIBLE COMPONENT OF GRAVIMETRIC SAMPLES, BY SPECTROGRAPHIC METHODS

\begin{tabular}{l|c|c}
\hline \multicolumn{1}{c|}{ Element } & Sieving (\%) & Hot Pressing (\%) \\
\hline Tungsten & 90 & In quantity* \\
Cobalt & 6 & In quantity* \\
Titanium & $1-5$ & -5 \\
Silica & $1-5$ & $1-5$ \\
Aluminium & 1 & $1-5$ \\
Magnesium & $0 \cdot 1$ & $0 \cdot 1-1$ \\
Iron & 1 & $1-5$ \\
Any other element & - & - \\
\hline
\end{tabular}

*Sample collected was too small for accurate measurementprobably of the same order as that found in sample from sieving room.

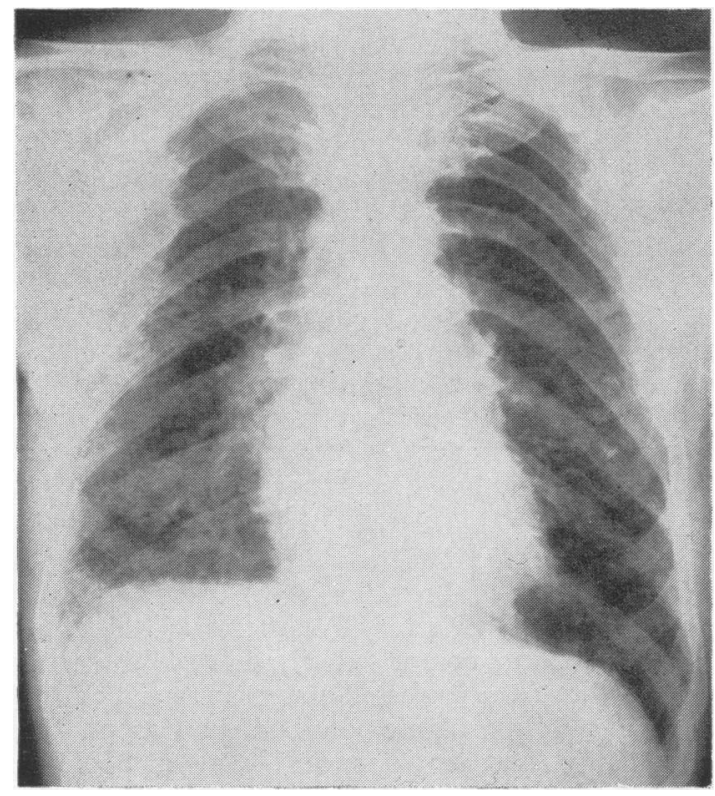

Fig. 2.-Radiograph of Case 1, January 1947, after 13 years' exposure. (subject " $L ")$. The results are given in Tables 2 and 2a.

\section{Case Reports}

Case 1 (born in 1888).-From 1901 to 1933 he was employed as a coremaker in various iron foundries. Very occasionally he worked as a moulder. For the next 17 years, from 1934 to 1951 , he worked in a factory manufacturing hard metal tools. Initially he did most of the jobs, but later was employed in mixing the powders. From 1947 to 1951 he worked as assistant at the final sintering oven.

Clinical Record.-In January 1947 he attended hospital with a three-year history of persistent dry cough, increasing shortness of breath, and pain and tightness in the chest. On examination the chest was rigid, the fingers were slightly clubbed, and the blood pressure was 130 / $86 \mathrm{~mm}$. Hg. A radiograph (Fig. 2) revealed heavy hilar shadows, a marked increase of linear markings, and the presence of profuse micro-nodular opacities. These changes were present in all zones and especially heavy in the mid and lower zones.

In June 1951 he was admitted to hospital complaining of increasing dyspnoea and tightness in the chest, cough with sputum, aching pain in the right chest, lassitude, loss of weight, and occasional night sweats for a few months. Examination revealed râles at the right base. A radiograph showed increased shadowing above the right diaphragm. The Westergren sedimentation rate was $53 \mathrm{~mm}$. in one hour. One sputum culture revealed tubercle bacilli.

Until his death in June 1955 there was a gradual clinical deterioration and an extension of physical signs in the right lung. Serial radiographs showed progressive changes in the right lung. By May 1952 there was a dense rounded opacity in the right lower zone with a shaggy indefinite outline and central cavitation. A radiograph in 1954 revealed a similar appearance, though the mass was larger.

Tubercle bacilli were cultured again in August 1952 and in January 1955. Though it was apparent on clinical and radiological grounds that the mass in the right lower zone was a neoplasm he was treated with intermittent courses of streptomycin, P.A.S., and isoniazid.

Pathological Findings.-At autopsy the mucosa of the trachea was found to be granular and there was some muco-purulent exudate. There was a small amount of clear fluid in the left pleural cavity; the right pleural cavity was obliterated by adhesions. The left lung showed slight anthracosis. There were some old, healed scars, but no evidence of active tuberculosis. There was a tumour of the right lower lobe bronchus, which invaded the greater part of the right lung. Hilar and para-aortic glands were enlarged and invaded by tumour. The only other significant finding was some neoplastic invasion of the capsule of the right kidney.

Microscopic examination of histological sections of the left lung showed diffuse interstitial fibrosis, marked peribronchial and perivascular fibrosis, and marked hyperplasia and metaplasia of bronchial epithelium. There was variation in the degree of vascularity of the 
fibrous tissue, some areas showing marked vascularity whilst other areas, mainly hyalinized, were entirely free from vessels. There was slight anthracotic pigmentation. No giant cells were seen and there was no evidence of tuberculosis. Sections from the right lung showed similar features complicated by the presence of an anaplastic adenocarcinoma. The fibrosis present in the lung did not appear to be a stromal reaction that might be related to carcinoma. The general appearance was that of a non-specific fibrosis (Figs. $3 a$ and $3 b$ ).

Case 2 (born 1897). - Until he joined the Army in 1915, he was employed in a machine tool factory boring steel, then as a bread roundsman, and from 1920 to 1942 pressing wood pulp in a textile factory. Since 1942 he has been employed as a millwright in general maintenance at a factory manufacturing hard metal tools. He also stripped and cleaned 10 ovens and their flues twice a week. Since 1956 he has been doing light work, including stock taking.

Clinical Record.-A radiograph in January 1952 (Fig. 4) revealed some increase in the transverse diameter of the heart, very prominent hilar shadows, and in the mid and lower zones a marked increase of linear markings and the presence of scattered micro-nodular opacities. Some confluence of these opacities was present in the lower zones, especially on the left side. He was first seen in January 1954 and gave a five-year history of cough with copious frothy sputum, of dyspnoea on exertion, and of recent left chest pain and haemoptysis. On examination the chest was rigid and emphysematous, the breath sounds were distant, râles were audible at the bases, and the blood presure was $190 / 120 \mathrm{~mm}$. $\mathrm{Hg}$. $A$ radiograph at this time revealed increased prominence of the hilar shadows and the same distribution of the linear and micro-nodular opacities, though there was an apparent contraction and hardening of the linear opacities and an increased profusion of the micro-nodular opacities. The Westergren sedimentation rate was $10 \mathrm{~mm}$. in one hour. The haemoglobin was $14.6 \mathrm{~g} . / 100 \mathrm{ml}$., the red blood cell count $4,900,000 / \mathrm{c} . \mathrm{mm}$., and the leucocyte count $8,400 /$ c.mm. (68\% polymorphs, $25 \%$ lymphocytes, $5 \%$ monocytes, and $2 \%$ eosinophils). The Wasserman and Kahn tests were negative. Sputum cultures were negative for tubercle bacilli.

In March 1956 he was admitted to hospital with an acute respiratory infection. He was cyanosed, breathless, and had increased cough with purulent sputum. There were increased signs at the bases of both lungs, slight hepatic enlargement, tachycardia, slight oedema of the ankles, and elevation of the jugular pressure. The blood pressure was $120 / 70 \mathrm{~mm}$. $\mathrm{Hg}$. The haemoglobin was $15.6 \mathrm{~g} . / 100 \mathrm{ml}$., the red cell count $5,400,000 / \mathrm{c} . \mathrm{mm}$., and the leucocyte count $9,800 /$ c.mm. ( $83 \%$ polymorphs, $13 \%$ lymphocytes, $2 \%$ large monocytes, and $2 \%$ eosinophils). Urine analysis revealed $0.35 \mathrm{~g}$. of albumin and the presence of casts. An electrocardiogram showed left axis deviation. The signs of early cardiac failure cleared rapidly as the respiratory infection responded to antibiotics.

For the past five years he has suffered from severe persistent dyspnoea on exertion with wheezing and

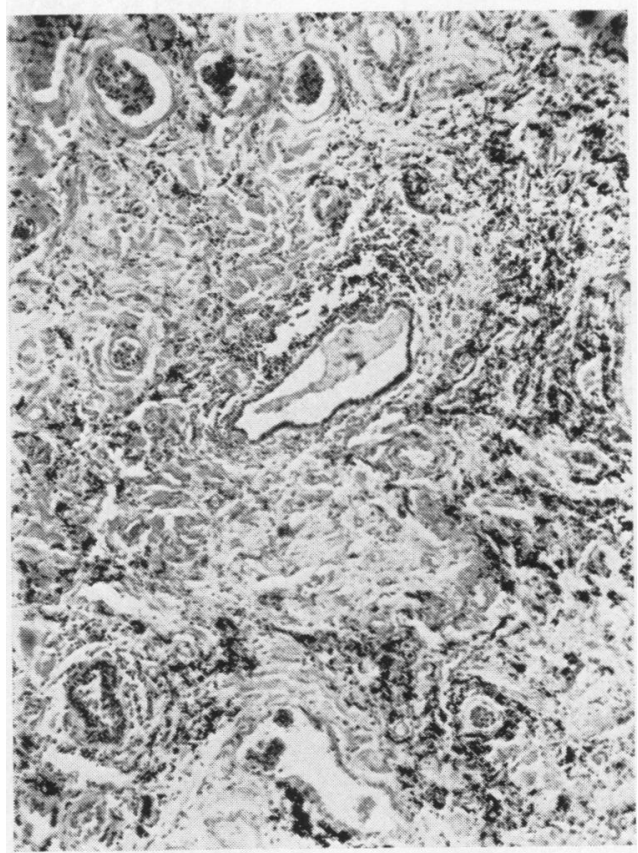

Fig. 3a.-Section of lung from Case 1 showing diffuse fibrosis and marked peribronchial and perivascular fibrosis. In the bottomleft hand corner is illustrated a small bronchus showing marked hyperplasia and metaplasia of the lining epithelium. ( $\times 75$.)

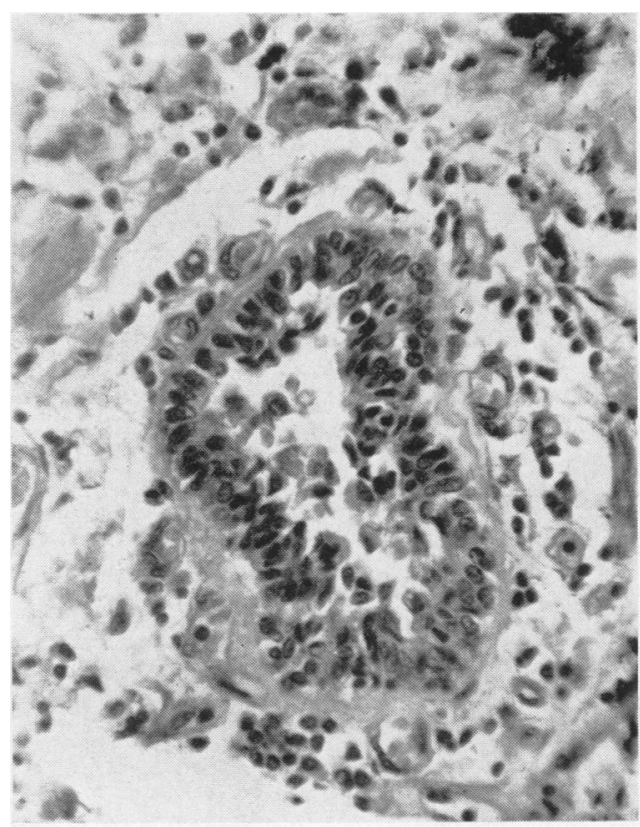

FIG. 3b.- Shows the airway seen in Fig. 3a at higher magnification. $(\times 290$. 


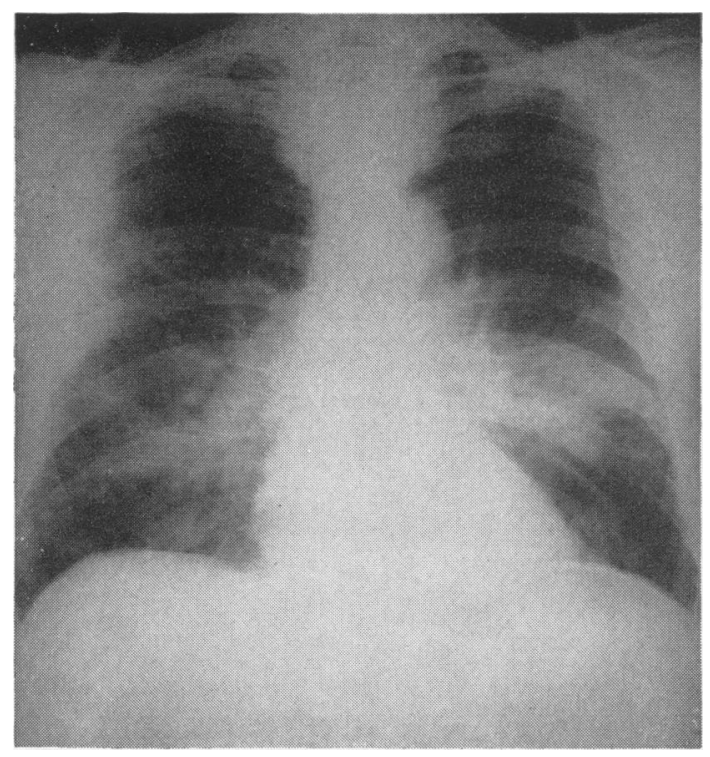

Fig. 4.-Radiograph of Case 2, January 1952, 10 years' exposure.

tightness, persistent cough and sputum with infrequent sputum staining and occasional palpitations. During the winters, he has been away from work for periods of several months with respiratory infections and exacerbations of symptoms. In March 1961 examination revealed a blood pressure of $170 / 100 \mathrm{~mm}$. $\mathrm{Hg}$, a rigid

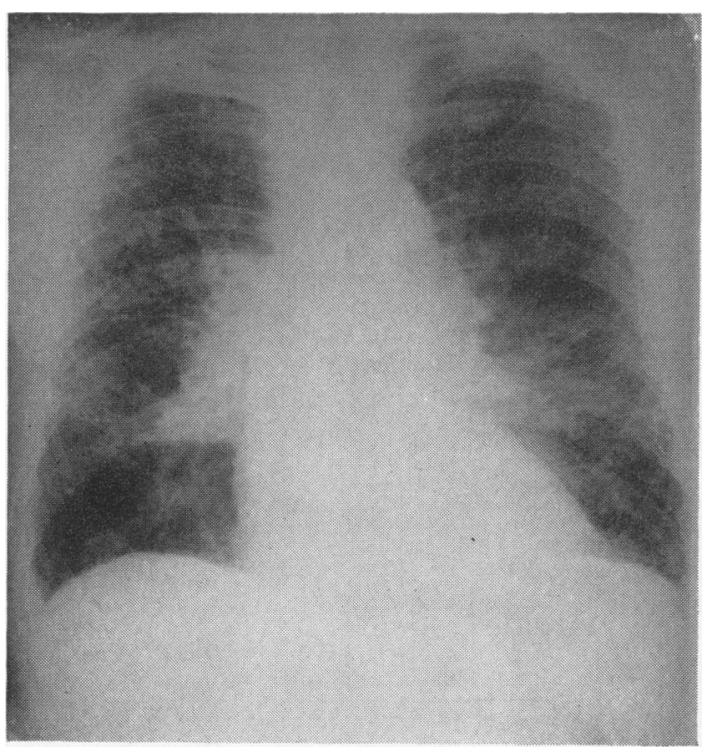

Fig. 5.-Radiograph of Case 2, March 1961, 19 years' exposure. emphysematous chest, and the presence of basal râles. The liver and spleen were palpable. A Heaf test was positive. The urine analysis was normal. A radiograph (Fig. 5) revealed the presence of heavy linear markings and profuse micro-nodular opacities in the right upper zones, further contraction of the linear opacities in the mid and lower zones, and increased translucency in the right mid and lower zones. An electrocardiogram showed supraventricular and ventricular ectopic beats in the chest leads and left axis deviation. The haemoglobin was $13.7 \mathrm{~g} . / 100 \mathrm{ml}$. and the leucocyte count $5,000 / \mathrm{c} . \mathrm{mm}$. (65\% polymorphs, $30 \%$ lymphocytes, $4 \%$ large monocytes, and $1 \%$ eosinophils). The blood urea was $28 \mathrm{mg}$./ $100 \mathrm{ml}$. The plasma proteins were $7.5 \mathrm{~g}$. $/ 100 \mathrm{ml}$. (albumin $4 \cdot 1$, globulin $3.4: a_{1}$ globulin $0.3 \mathrm{~g} . / 100 \mathrm{ml}$., $a_{2} 0.7$ g. $/ 100 \mathrm{ml}$., $\beta 0.9$ g. $/ 100 \mathrm{ml}$., and $\gamma 1.5 \mathrm{~g} . / 100 \mathrm{ml}$.). I.iver function tests were normal.

Physiological Assessment.-The physiological findings are summarized in the Appendix. The ventilatory capacity was moderately reduced and increased slightly after adrenalin. The percentage of the forced vital capacity which could be expelled in one second was normal. The lung airways resistance and static compliance were normal; the dynamic compliance was reduced. The total lung capacity and its subdivisions were normal. The pulmonary diffusing capacity was low. The patient hyperventilated on exercise breathing air; the hyperventilation was associated with a low arterial carbon dioxide tension, and a fall in the arterial oxygen tension from its resting value.

The patient's dyspnoea on exertion was probably the result of hyperventilation and some reduction in ventilatory capacity. The low diffusing capacity and the arterial blood gas changes, together with the normal forced expiratory volume ratio and airways resistance, suggested some degree of alveolar capillary block. But the difference between static and dynamic compliance and the moderate reduction in ventilatory capacity indicated also some degree of obstructive lung disease.

Case 3 (born 1910).-He started work in 1924 and was employed in turn as a spinner in various cotton mills for nine years, as a maintenance fitter for six years, and as a storekeeper for seven years. He was next employed as a steel hardener for nine years. In June 1955 he started work in a factory manufacturing hard metal tools. He was employed mixing the powders with a hand-operated mixer in a separate room with a low ceiling. He then fed the mixed powder into an extruding machine, placed the extruded material in an oven and later removed it. After 21 months he developed symptoms and gave up this work in March 1957. He restarted work in the same factory in July 1957 partly as a gardener and partly as a storekeeper. Apart from three months' sickness absence in 1958 he remained in this employment until May 1960 when he returned to steel hardening.

Clinical Record.-In November 1952 he underwent a left orchidectomy for tuberculous epididymo-orchitis. His health was otherwise good and he had no respiratory symptoms. A radiograph was normal. For the next four years he remained well and periodic radiographs were normal. 
He reattended in March 1957, 17 months after the last normal radiograph, with six weeks' history of cough with sputum, moderate dyspnoea on exertion, tightness across the chest, and lassitude. Examination revealed harsh breath sounds and the presence of basal râles. A radiograph (Fig. 6) revealed a well-marked increase in linear markings, the presence of profuse micro-nodular opacities in all zones, but particularly heavy in the mid and lower zones. Repeated sputum cultures for tubercle bacilli were negative. The Westergren sedimentation rate was $3 \mathrm{~mm}$. in one hour. The haemoglobin was $15.5 \mathrm{~g} . / 100 \mathrm{ml}$., and the leucocyte count $8,700 /$ c.mm. $(69 \%$ polymorphs, $23 \%$ lymphocytes, $6 \%$ large monocytes, and $2 \%$ eosinophils). Urine analysis was normal. Following symptomatic treatment his symptoms slowly improved and were noticeably less by July 1958 .

In Octobar 1958 he developed a tuberculous right epididymo-orchitis. A radiograph at that time revealed no change. He was treated with streptomycin, isoniazid, and P.A.S. until September 1959. He was by this time virtually free of respiratory symptoms. His subsequent progress has been uneventful.

In March 1961 examination was normal, the blood pressure being $140 / 80 \mathrm{~mm}$. Hg. A Heaf test was positive. A chest radiograph revealed some contraction of the linear opacities and the same distribution and profusion of the micronodular opacities. The haemoglobin was 13.1 g. $/ 100 \mathrm{ml}$., the leucocyte count $5,000 / \mathrm{c} . \mathrm{mm}$. $(65 \%$ polymorphs, $30 \%$ lymphocytes, $4 \%$ large monocytes, and $1 \%$ eosinophils) and the Westergren sedimentation rate $11 \mathrm{~mm}$. in one hour. The plasma proteins were $7 \cdot 7 \mathrm{~g} . / 100 \mathrm{ml}$. (albumin 4.0, globulin 3.7: $a_{1}$ globulin, $\alpha_{2} 0.7 \mathrm{~g} . / 100 \mathrm{ml}$., $\beta 1.0 \mathrm{~g}$. $/ 100 \mathrm{ml}$., and $\gamma 1.6 \mathrm{~g} . / 100 \mathrm{ml}$.). Liver function tests were normal.

Physiological Assessment.-The physiological findings are summarized in the Appendix. The ventilatory capacity, lung airways resistance, total lung capacity, and its subdivisions were within normal limits; the lung compliance (both static and dynamic) and diffusing capacity were somewhat reduced. The patient ventilated normally on exercise, but the arterial blood oxygen tension, which was normal at rest, fell on near maximal exercise. This finding confirmed the small diffusion defect which, in the presence of a reduced compliance, was probably due to slight pulmonary fibrosis.

Case 4 (born 1894). - In 1903 he was employed in turn in cycle repairing, brake testing, and again in cycle repairing, until he joined the Army in 1916. In 1919 he worked in a furniture shop and then as a packer. From 1924 to 1946 he was employed in a factory manufacturing hard metal tools as a shaper. He then retired for health reasons. For the last 10 years of the period dust extraction was operating.

Clinical Record.-From 1937 he suffered from slight dyspnoea on exertion, slight cough, and occasional palpitations. A radiograph taken by the miniature mass radiography unit in October 1947 (Fig. 7) revealed an enlarged heart, punctiform nodules, and increased linear markings over two-thirds of each lung field, and an area of increased translucency at the right base with obliteration of both costophrenic angles.

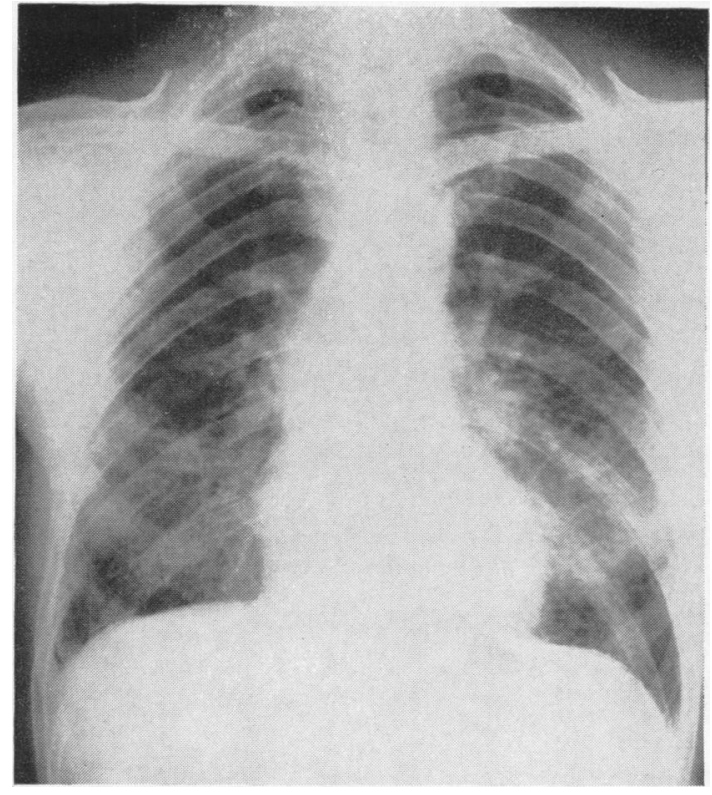

FIG. 6.-Radiograph of Case 3, March 1961, 17 months' exposure.

In July 1948 he first attended hospital complaining of increased dyspnoea on exertion, cough, and palpitations, also loss of weight, lassitude, headache, and soreness of

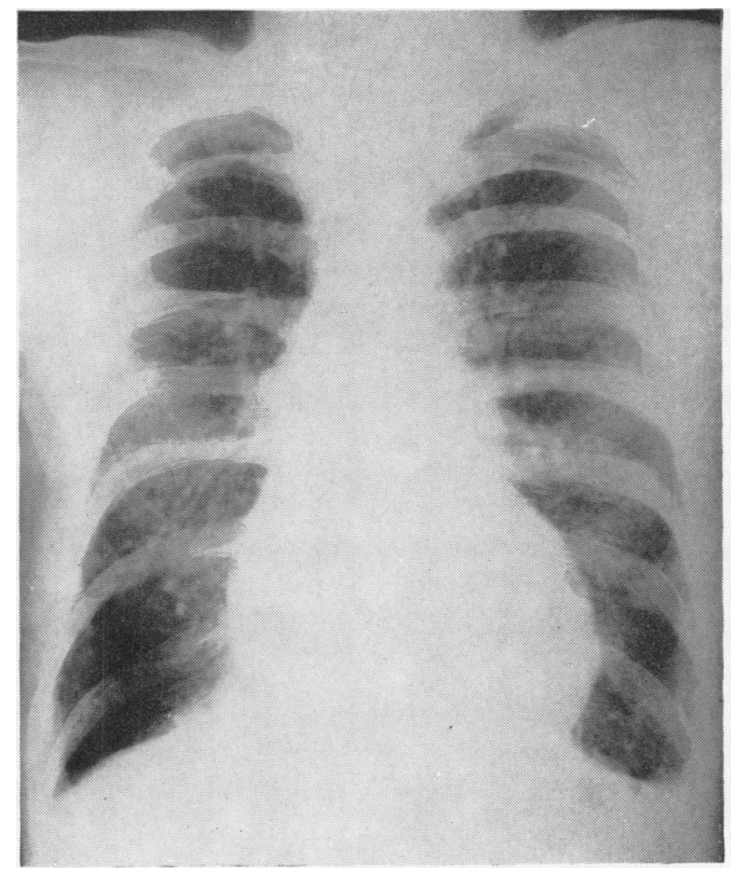

Fig. 7.-Radiograph of Case 4, October 1947, 23 years' exposure. 


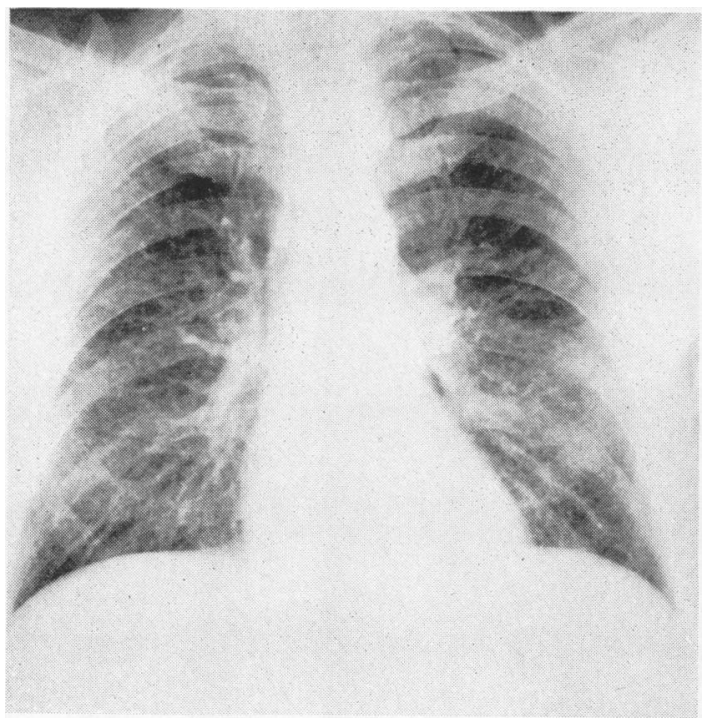

FIG. 8.-Radiograph of Case 5, December 1961, 15 years' exposure.

the throat and mouth. The blood pressure was $275 / 105$ $\mathrm{mm}$. Hg. Aortic incompetence was present, and the chest was rigid and emphysematous. Urine analysis revealed the presence of albumin. The haemoglobin was $14 \cdot 3 \mathrm{~g}$./ $100 \mathrm{ml}$., the red blood cell count 4,760,000/c.mm. $(1 \%$ reticulocytes) and the leucocyte count 8,500/c.mm. (63\% polymorphs, $30 \%$ lymphocytes, $5 \%$ monocytes, and $2 \%$ eosinophils).

He was admitted to hospital in January 1949 with a coronary thrombosis and a left pleural effusion, due to pulmonary infarction. An electrocardiogram showed changes consistent with anterior myocardial infarction, complete heart block, and left axis deviation. The haemoglobin was $15.5 \mathrm{~g} . / 100 \mathrm{ml}$, the red blood cell count $5,110,000 /$ c.mm. $(0 \cdot 5 \%$ of reticulocytes $)$ and the leucocyte count $22,000 /$ c.mm. ( $73 \%$ polymorphs). The pleural fluid was lymphocytic and sterile on culture. The sputum was negative for tubercle bacilli on culture. In 1951 he had a cerebral haemorrhage and died. No autopsy was performed.

Case 5 (born 1913).-He first worked as a grocer for 10 years and then as a turner for eight years making steel dies, until 1946. For 16 years, since 1946 he has been employed as a turner in the shaping department of a factory manufacturing hard metal tools. The work involves the use of a diamond wheel and is carried out before final sintering.

Clinical Record.-His health has always been good, his only symptom being a recent dry cough. Examination was normal, the blood pressure being $125 / 80 \mathrm{~mm}$. $\mathrm{Hg}$. A radiograph in December 1961 (Fig. 8) revealed an increase of linear markings and the presence of scattered punctiform opacities particularly in the mid and lower zones. Urine analysis was normal. A Heaf test was positive. The haemoglobin was $14.9 \mathrm{~g} . / 100 \mathrm{ml}$. and the leucocyte count $7,000 / \mathrm{c} . \mathrm{mm}$. (68\% polymorphs, $21 \%$ lymphocytes, $5 \%$ large monocytes, $4 \%$ eosinophils, and $2 \%$ basophils). The Westergren sedimentation rate was $2 \mathrm{~mm}$. in one hour. The plasma proteins, the globulin fractions, and liver function tests were normal.

Case 6 (born 1921).-After one year in the boot and shoe trade he started work at an engineering factory as a surface grinder in 1938. Three years later he transferred to the tool department. Initially he was partly engaged in brazing hard metal tips onto steel tools and partly in sharpening their cutting edges by dry grinding with diamond and carborundum wheels. After a few years he became wholly engaged in dry grinding hard metal tools.

Clinical Record.-In October 1946 a routine radiograph was normal. He first attended hospital in August 1949 with six months' history of dry cough. Examination was normal. A radiograph (Fig. 9) revealed the presence of increased linear markings and faint nodular opacities in the mid and upper zones.

During the next seven years he remained well and his weight increased, though his dry cough persisted intermittently. Periodic examinations were normal. Serial radiographs showed slowly increasing changes. A radiograph in June 1954 (Fig. 10) revealed slight widening of the superior mediastinum and prominence of the hilar shadows especially on the left side, also a marked increase in linear markings, and the presence of profuse nodular opacities in all zones, these changes being most evident in the right lung in the upper and lower zones.

In June 1956 he reattended hospital following a respiratory infection with two months' history of slight discomfort in the chest, nasal catarrh, and cough with sputum. Examination revealed some restriction of chest expansion and the presence of occasional mid and lower zone rhonchi. A radiograph (Fig. 11) revealed further widening of the superior mediastinum with rotation of the heart and traction of the trachea to the right, a very heavy left hilar shadow and a very marked increase of linear markings particularly in the upper and right lower zones, also the presence of extremely profuse nodular opacities in all zones with areas of confluent shadowing in the right lower zone and the left mid-zone near the left hilum. Direct examination of sputum for tubercle bacilli was negative. From July 1956 to April 1957 he was given $200 \mathrm{mg}$. of isoniazid and $16 \mathrm{~g}$. of P.A.S. daily, whilst remaining at work. Following this treatment there was no radiographic clearing. A Heaf test was negative, a Mantoux test was positive to 10 tuberculin units, a Westergren sedimentation rate was $6 \mathrm{~mm}$. in one hour, the plasma proteins were normal and a Wasserman test was negative. The findings on examination were unchanged, the blood pressure being $150 / 70 \mathrm{~mm}$. $\mathrm{Hg}$.

From March 1959 to September 1959 he was treated with $10 \mathrm{mg}$. of prednisolone, $200 \mathrm{mg}$. of isoniazid, and 16 g. P.A.S. daily, whilst remaining at work. No radiographic clearing was seen following this treatment. A radiograph in September 1961 (Fig. 12) revealed increased distortion of the pulmonary architecture. There were further widening of the superior mediastinum, 


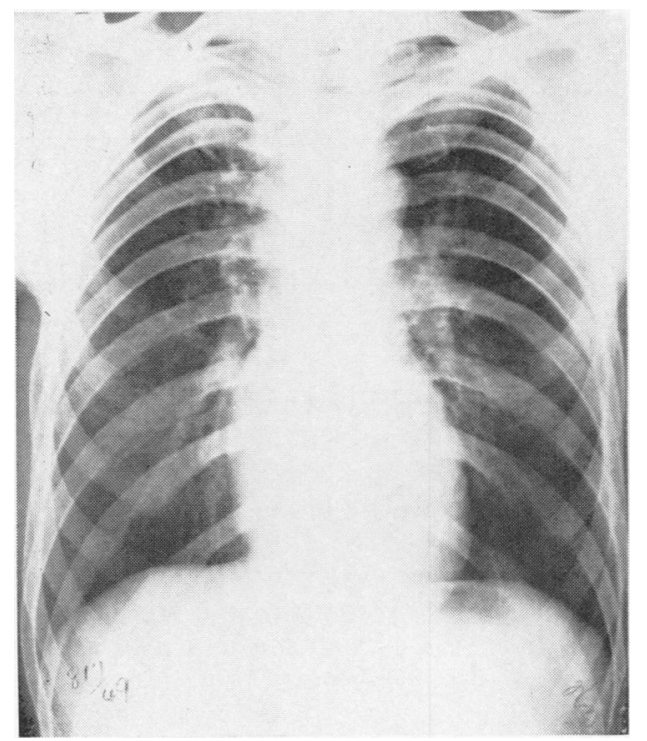

Fıg. 9.-Radiograph of Case 6, August 1949, eight years' exposure.

increased rotation of the heart and traction of the trachea to the right, and additional areas of confluence in the upper zones.

During the past five years he has remained well and has continued to gain weight. He has complained intermittently of a dry cough and latterly of slight dyspnoea on exertion. Serial radiographs have shown slowly progressing changes in both lungs.

Table 3 provides a summary of these six cases.

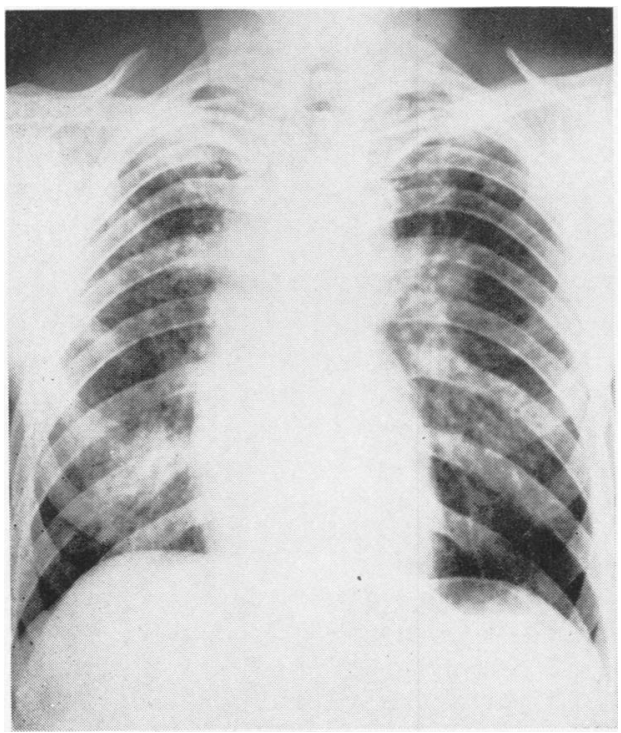

Fig. 11.-Radiograph of Case 6, June 1956, 15 years' exposure.

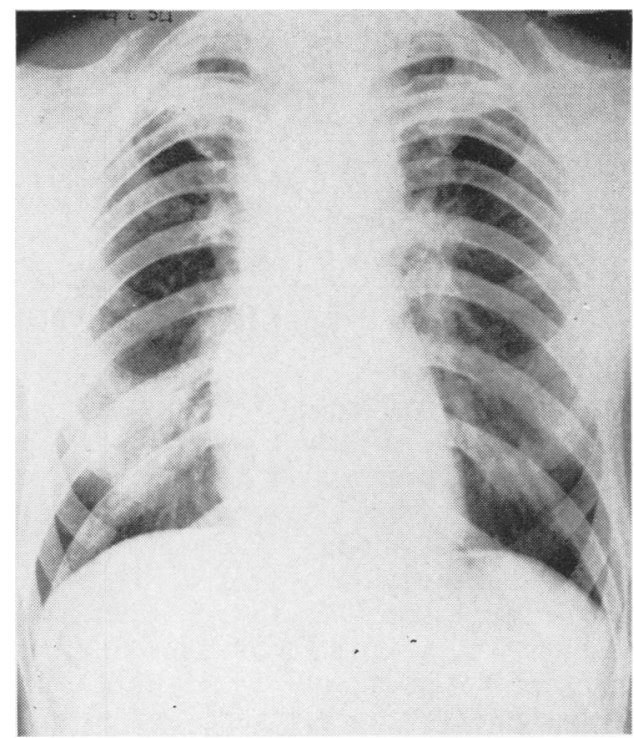

Fig. 10.-Radiograph of Case 6, June 1954, 13 years' exposure.

\section{Discussion}

Past experience in a number of hard metal factories has shown that there have been complaints of cough, expectoration, shortness of breath, and tightness of the chest. These symptoms are comparatively mild in the majority of workers. A few individuals experience well-marked respiratory distress towards the end of the working day. The

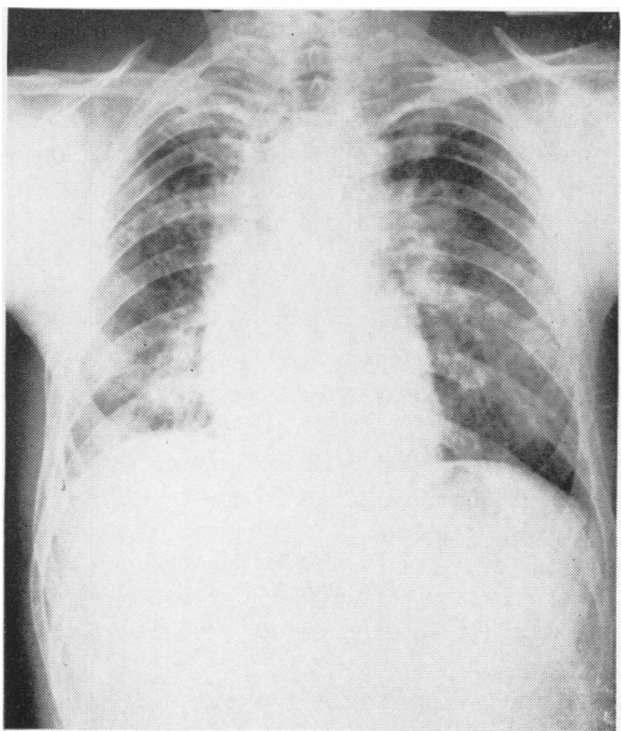

FIG. 12.-Radiograph of Case 6, September 1961, 20 years' exposure. 
TABLE 3

SUMMARY OF CASES

\begin{tabular}{c|c|c|c|c}
\hline Case & Year of Birth & Occupation & Exposure (years) \\
\hline 1 & 1888 & Powder worker & $1934-1951: 17$ \\
2 & 1897 & Millwright & $1942-1962: 20$ & 190 \\
3 & 1910 & Powder worker & $1955-1957:$ yr 10 mths \\
4 & 1894 & Shaper & $1924-1946: 22$ & 1952 \\
5 & 1913 & Shaper & $1946-1962: 16$ & 1957 \\
6 & 1921 & Grinder & $1941-1962: 21$ & 1947 \\
\hline
\end{tabular}

results of the physiological tests obtained at the factory survey showed that a change in respiratory mechanics was occurring during a day's exposure to dust in two of the 19 workmen tested, though some other of the workers did complain of cough, wheezing, and shortness of breath. Both of these men experienced less distress when wearing masks. In the men with severe symptoms there appears to be considerable variation in the length of exposure before symptoms arise but in some these may develop quite quickly. The majority of those developing severe symptoms leave and are thus excluded from the industry. At an early stage such symptoms may be reversible on withdrawal from exposure.

The extent of the relation between susceptible individuals with respiratory symptoms and acute physiological changes and those individuals with established hard metal disease and permanent pulmonary damage is uncertain.

Hard metal disease may arise abruptly without preliminary respiratory symptoms. One man (Case 3), who had been under regular clinical and radiological surveillance for five years before exposure started, developed symptoms after 21 months, and his radiograph showed widespread pulmonary changes six weeks later. The disease may develop with little or no preceding respiratory symptoms and with no symptoms of significance with established minimal disease as in Case 5, and marked radiographic changes may be associated with mild symptoms as in Case 6. Morbidity appears to be extremely low and only a very small proportion of those exposed become affected. Moschinski et al. (1959) believe that factors of individual susceptibility play a significant part in the development and subsequent course of the disease. They cite the example of a father and son who both developed the disease. Degrees of susceptibility would account for the marked variation in the length of exposure, the severity of the disease, and the rates of progression.

There have been reports of radiological clearing on withdrawal from exposure (Miller et al., 1953; Lundgren and Öhman, 1954). This has not been obvious in our cases. It seems likely that the progress of the disease is affected by continued exposure. Since the disease was first detected radiologically Cases 2, 3, and 6 have been studied for nine, four, and 12 years respectively. There has been gradual radiological progression and increasing respiratory insufficiency with continued exposure in Case 2, whereas in Case 3 without further exposure minimal radiological progression has been accompanied by gradual disappearance of respiratory symptoms. In Case 6 there has been steady radiological progression accompanied by only slight symptoms with continued exposure.

It is possible that the pulmonary response is of the nature of a hypersensitivity. This is suggested by the reversibility of the symptoms, by the occasional radiological clearing on withdrawal from exposure, and by the precipitation of the symptoms on reexposure (Miller et al., 1953). The animal experiments of Delahant (1955) support this view. This type of response has been suggested by Miller et al. (1953), and by Moschinski et al. (1959). Lundgren and Öhman (1954) have pointed out that there is no correlation between skin allergy as demonstrated by skin tests and pulmonary symptoms.

The pathological findings in Case 1 of our series are broadly similar to those described in the literature and correlate well with the physiological changes found in Cases 2 and 3, which indicated mild alveolar diffusion defects.

As far as we are aware Case 1 of our series is the first example reported of carcinoma of the bronchus developing in a patient suffering from hard metal disease. The finding of bronchial epithelial hyperplasia and metaplasia is of interest in the light of the animal experiments of Schepers (1955) and of Kaplun and Mezencewa (1960), and of Heath (1960).

Miller et al. (1953) found raised plasma protein levels with elevation of globulin in the cases he described. In our series the plasma proteins were estimated by electrophoresis in three cases. The methods and normals were based on the paper by Salt (1956). In Cases 2 and 3 minor abnormalities were found. High haemoglobin levels were found in three of our series. These levels though within the 
TABLE 4

RANGE OF CONCENTRATIONS (p.p. ml.) FOUND BY OTHER WORKERS

\begin{tabular}{|c|c|c|c|c|}
\hline Department & $\begin{array}{c}\text { Moschinsky } \\
\text { et al. }\end{array}$ & $\begin{array}{l}\text { Lundgren } \\
\text { and Ohman }\end{array}$ & $\begin{array}{l}\text { Fairhall } \\
\text { et al. }\end{array}$ & Our Own \\
\hline $\begin{array}{l}\text { Powder } \\
\text { Forming }\end{array}$ & $\begin{array}{l}300-1,200 \\
200-1,400\end{array}$ & $\begin{array}{l}10-2,000 \\
10-2,000\end{array}$ & \} (average) & $\begin{array}{l}405-505 \\
195-1,230\end{array}$ \\
\hline
\end{tabular}

upper limits of normal are in line with the findings of Miller et al. (1953) and S. G. Rainsford (1959, personal communication).

Dust concentrations reported by other workers who have investigated hard metal disease are given in Table 4 (Fairhall, Keenan, and Brinton, 1949; Lundgren and Öhman, 1954; Moschinski et al., 1959). Unfortunately differences in sampling technique and instruments make comparison of doubtful validity, but it appears that the dust concentrations we measured were of the same order as reported elsewhere, and this perhaps indicates that it should not be assumed that previous cases of this disease have only occurred under conditions of high dust concentration. In Russia maximum acceptable concentrations are $0.5 \mathrm{mg} . / \mathrm{m}^{3}$ for cobalt (cobalt oxide) and $6 \mathrm{mg} . / \mathrm{m}^{3}$ for tungsten and tungsten carbide (Elkins, 1961). We found a concentration of between 400 to 500 particles per ml. (p.p.ml.) close to the working positions of the men and about 200 p.p.ml. away from these positions, and at slitting (cutting with a thin grinding wheel) 1,230 p.p.ml. Background dust levels contributed 100 to 150 p.p.ml. The analysis of the dust depended upon the composition of the materials being handled or machined and therefore varied throughout the factory.

The agent responsible for hard metal disease is as yet unknown. Cobalt in animal experiments has been shown to produce pulmonary lesions, hyperglobulinaemia, and erythrocytaemia, and to be the toxic constituent in hard metal. In man cobalt is known to produce a skin allergy and an erythrocytaemia. Tungsten, tungsten carbide, and titanium have been found to be relatively inert in animal experiments, and tungsten and titanium are comparatively harmless in man. Post-mortem analysis of lungs of hard metal workers have shown the presence of tungsten and titanium, but cobalt has not been found, perhaps due to its high solubility in plasma. Nagelschmidt (1960) has suggested that the reaction with a soluble dust is an interstitial or disseminated fibrosis and with an insoluble one a nodular or focal fibrosis.

The acquisition of more information on the risks of grinding hard metal is desirable as this process is carried out in many engineering factories. The three cases described by Miller et al. (1953) and our sixth case were grinders, although Moschinski et al. (1959) were of the opinion that after final sintering there was no significant dust hazard. Miller et al. (1953) have demonstrated the toxic properties of dust derived from grinding hard metal in animal experiments.

We are grateful to Dr. P. Tyson Davidson and Dr. J. E. Cottrell who first surveyed hard metal workers in this country.

We are deeply indebted to the staff of the Pneumoconiosis Research Unit for their help and advice; to Dr. C. B. McKerrow and Dr. J. C. Gilson for carrying out the physiological tests at the factory survey and for interpreting the results, to Mr. J. W. Skidmore for dust measurements, and Dr. J. E. Cotes for carrying out the physiological studies in Cases 2 and 3 and for interpreting the results; also to Miss Pamela Edwards of this unit.

We are also grateful to Dr. A. A. White and Dr. R. B. Mayfield for allowing us to include Case 6; and to Dr. G. E. Smith, Dr. Ethel Browning, Dr. J. Gwynne Morgan, Dr. D. Frost, Dr. J. A. Duncan, and Dr. A. I. G. McLaughlin for assistance; to Dr. A. P. Prior, Dr. D. Rivers, and Professor J. P. Wyatt for advice on pathology and to Dr. Gordon Evans for the Mass Radiography Surveys; to Miss A. L. Hebdeb for radiograph reproductions, and to Mr. S. Gaunt for photomicrographs, also to Miss J. M. Gick for secretarial assistance.

Finally we should like to thank Dr. T. A. Lloyd Davies for his encouragement and the members of the firms concerned for their wholehearted co-operation.

\section{REFERFNCES}

Ahlmark, A., Bruce, T., and Nyström, А. (1961). Silicosis and Other Pneumoconioses in Sweden, p. 390. Svenska Bokförlaget. Stockholm

Browning, E. (1960). In Modern Trends in Occupational Health, ed. R. S. F. Shilling, p. 85. Butterworth, London.

(1961). Toxicity of Industrial Metals, p. 115 . Butterworth, London.

Caujolle, F., and Meynier, D. (1959). Rev. Path. gén., 59, 245.

Delahant, A. B. (1955). A.M.A. Arch. industr. Hith, 12, 116

Elkins, H. B. (1961). Arch. environm. Hith, 2, 45.

Elkins, H. B. (1961). Arch. environm. Hlth, 2, 45 . (1947). Occup. Med., 4, 371.

Keenan, R. G., and Brinton, H. P. (1949). Publ. Hlth Rep. (Wash.), 64, 485.

Frederick, W. G., and Bradley, W. R. (1946). Rep. of 8th Ann Meeting of Amer. Industr. Hyg. Ass. Chicago.

Harding, H. E. (1950). Brit. J. industr. Med., 7, 76.

Heath, J. C. (1960). Brit. J. Cancer, 14, 478.

Husten, K. (1959). Arch. Gewerbepath. Gewerbehyg., 16, 721.

Jobs, H., and Ballhausen, C. (1940). Vertrauensarzt, 8, 142.

Kaplun, Z. S. (1957). Iseretyne Met., 9, 42.

Kaplun, Z. S. (1957). Iseretyne Met., 9, 42. Epidem. (Praha), 4, 390. Karth, B. (1948). Rep. of meeting of Swedish Ass. Int. Med.

Karth, B. (1948). Rep. of meeting of Swedish Ass. Int. Med. 325, 259 .

McKerrow, C. B., Roach, S. A., Gilson, J. C., and Schilling, R. S. F (1962). Brit. J. industr. Med., 19, 1.

Magos, L. N., Timár, U. A., and Szandányi (1956). Quoted by Moschinski et al. (1959).

Miller, C. W., Davis, M. W., Goldman, A., and Wyatt, J. P. (1953) A.M.A. Arch. industr. Hyg., 8, 453.

Moschinski, G., Jurisch, A., and Reinl, W. (1959). Arch. Gewerbepath. Gewerbehyg., 16, 697.

Nagelschmidt, G. (1960). Brit. J. indıstr. Med., 17, 247. 
Salt, H. B. (1956). Clin. Chem., $21,35$.

Schepers, G. W. H. (1955). A.M.A. Arch. industr. Hlth, 12, 121, also 27134,137 , and 140

Schwartz, L., Peck, S. M., Blair, K. E., and Markuson, K. E. (1945). J. Allergy, 16, 51 .

Stokinger, H. F., and Wagner, W. D. (1958). A.M.A. Arch. industr. Hith, 17, 273 .
Uzman, L. L., and Rosen, H. (1954). Science, 120, 1031.

Volta, A., and Marinoni, U. (1951). Il Policlinico, Sez. Med., 58, 145. Wiele, G. (1951). Rep. symp. Rhine-Westphalia Inst. intern. Med.

Wolff, H. S., and Roach, S. A. (1961). In Inhaled Particles and Vapours Proc. Int. Symposium organized by the British Occupationa Hygiene Society, ed. C. N. Davies, p. 460. Pergamon Press, London.

APPENDIX

\section{Pulmonary Function Studies}

\begin{tabular}{|c|c|c|c|c|}
\hline & \multicolumn{2}{|c|}{ Case 2} & \multicolumn{2}{|c|}{ Case 3} \\
\hline $\begin{array}{l}\text { Age (years) } \\
\text { Ventilatory Capacity } \\
\text { Forced expiratory volume (F.E.V.1.0) (1.) } \\
\text { Forced expiratory volume after adrenalin (1.) } \\
\text { Forced vital capacity (F.V.C.) (1.) } \\
\text { Forced vital capacity after adrenalin (1.) } \\
\text { F.E.V. \% F.V.C. } \\
\text { F.E.V. \% F.V.C. after adrenalin }\end{array}$ & \multicolumn{2}{|c|}{$\begin{array}{l}63 \\
2 \cdot 03 \\
2 \cdot 18 \\
2 \cdot 90 \\
2 \cdot 80 \\
70 \\
78\end{array}$} & \multicolumn{2}{|c|}{$\begin{array}{l}51 \\
3 \cdot 08 \\
3 \cdot 08 \\
3 \cdot 65 \\
3 \cdot 70 \\
84 \\
83\end{array}$} \\
\hline $\begin{array}{l}\text { Lung Capacity (helium dilution method) } \\
\text { Total lung capacity (T.L.C.) (1.) } \\
\text { Functional residual capacity (F.R.C.) (1.) } \\
\text { Residual volume (R.V.) (1.) } \\
\text { Rd. V\% T.L.C. }\end{array}$ & \multicolumn{2}{|c|}{$\begin{array}{r}5.98 \\
3 \cdot 73 \\
2 \cdot 61 \\
43 \cdot 6\end{array}$} & \multicolumn{2}{|c|}{$\begin{array}{l}5 \cdot 72 \\
3 \cdot 70 \\
1 \cdot 78 \\
31 \cdot 2\end{array}$} \\
\hline $\begin{array}{l}\text { Pulmonary Diffusing Capacity (single breath method) } \\
\text { Diffusing capacity of lung (DLco) (ml. } / \mathrm{mm} . / \mathrm{mm} . \mathrm{Hg}) \\
\text { Diffusing capacity of membrane }\left(\mathrm{D}_{\mathrm{mco}}\right)(\mathrm{ml} . / \mathrm{mm} . / \mathrm{mm} . \mathrm{Hg}) \\
\text { Volume of lung capillary }\left(\mathrm{V}_{\mathrm{C}}\right)(\mathrm{ml} .)\end{array}$ & \multicolumn{2}{|c|}{$\begin{array}{l}13 \cdot 3 \\
24 \cdot 0 \\
43\end{array}$} & \multicolumn{2}{|c|}{$\begin{array}{l}18 \cdot 8 \\
32 \cdot 0 \\
66\end{array}$} \\
\hline $\begin{array}{l}\text { Lung Mechanics } \\
\text { Airways resistance on inspiration by body plethysmograph }\left(\mathrm{cm} . \mathrm{H}_{2} \mathrm{O} / 1 . / \mathrm{m} \text {.) }\right.\end{array}$ & \multicolumn{3}{|c|}{$\begin{array}{l}1.37 \\
\text { Flow rate up to } 0.51 . / \mathrm{sec} \text {. }\end{array}$} & 0.74 \\
\hline $\begin{array}{l}\text { Compliance by oesophageal balloon }\left(1 . / \mathrm{cm} . \mathrm{H}_{2} \mathrm{O}\right) \\
\text { Static } \\
\text { Dynamic }\end{array}$ & \multicolumn{2}{|c|}{$\begin{array}{l}0 \cdot 177 \\
0 \cdot 074\end{array}$} & \multicolumn{2}{|c|}{$\begin{array}{l}0 \cdot 10 \\
0 \cdot 129\end{array}$} \\
\hline 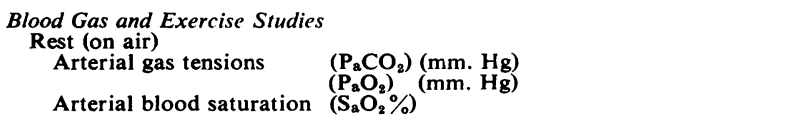 & \multicolumn{2}{|c|}{$\begin{array}{l}32 \cdot 1 \\
72 \cdot 2 \\
93 \cdot 9\end{array}$} & \multicolumn{2}{|c|}{$\begin{array}{l}41 \cdot 3 \\
94 \cdot 0 \\
99 \cdot 5\end{array}$} \\
\hline $\begin{array}{l}\text { Exercise } \\
\text { Treadmill speed (m.p.h.) } \\
\text { Treadmill slope (\%) }\end{array}$ & \multicolumn{2}{|c|}{$\begin{array}{r}2 \\
10\end{array}$} & \multicolumn{2}{|c|}{$\begin{array}{r}3 \\
16\end{array}$} \\
\hline 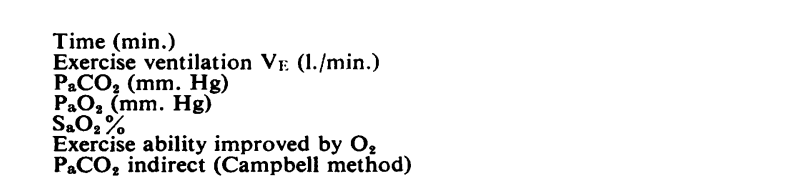 & $\begin{array}{l}\text { On Air } \\
1 \cdot 75 \\
51 \cdot 6 \\
31 \cdot 7 \\
61.7 \\
79 \cdot 0\end{array}$ & $\begin{array}{l}\text { On Oxygen } \\
1 \cdot 75 \\
35 \cdot 5 \\
42 \cdot 2 \\
100 \cdot 2 \\
\text { es }_{2 \cdot 6}\end{array}$ & $\begin{array}{l}\text { On Air } \\
2 \\
46 \cdot 6 \\
39 \cdot 1 \\
72 \\
93 \cdot 2\end{array}$ & $\begin{array}{l}\text { On Oxygen } \\
2 \\
42 \cdot 6 \\
45 \cdot 8 \\
\\
\overline{99} \cdot 1 \\
9 \cdot 4\end{array}$ \\
\hline
\end{tabular}

